Preprints of the

Max Planck Institute for

Research on Collective Goods

Bonn 2014/12

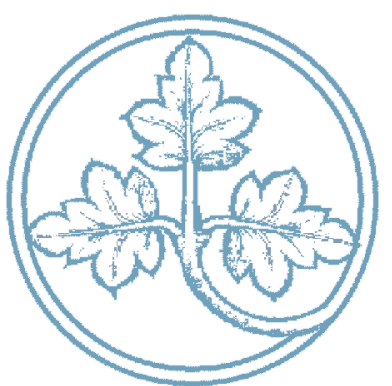

Yes Virginia, There is a

European Banking Union! But It May Not Make Your Wishes Come True

Martin Hellwig

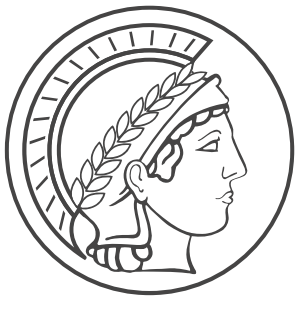




\title{
Yes Virginia, There is a European Banking Union! But It May Not Make Your Wishes Come True
}

\author{
Martin Hellwig
}

May 2014, final August 2014 


\title{
Yes Virginia, There is a European Banking Union! But It May Not Make Your Wishes Come True ${ }^{1}$
}

\author{
Martin F. Hellwig
}

\begin{abstract}
The paper discusses the prospects for European Banking Union as they appear in the summer of 2014. The first part gives an overview over the problems that gave rise to the Banking Union initiative, the second part discusses the legislative measures that have been taken towards this objective.

The euro area is currently suffering from low growth, high indebtedness of private households and firms, banks, and governments, and the weakness of financial institutions. Weakness of financial institutions affects the economy not only in countries with outright banking crises and sovereign debt crises, but also in some of the core countries that so far have seemed more stable. ECB policies have so far stabilized the system without solving the underlying problems. At the national level, political will to solve the underlying problems is missing; most governments prefer procrastination over cleanups, some governments do not have the funds to recapitalize the banks of their countries, and some governments like their banks to borrow from the ECB and lend to them.
\end{abstract}

The European Banking Union comes with a promise of reducing cross-border externalities in dealing with banks. However, the Single Supervisory Mechanism is hampered by the need to apply national laws that implement European directives; this makes for fragmentation even if the ECB is in charge. Moreover, procedures for the recovery and resolution of institutions in difficulties are problematic: If banks with systemically important operations in several countries enter into resolution, there is no way to prevent the breakdown of these operations and to limit the resulting systemic damage. Further, the legislation makes no provisions for the liquidity needed for maintaining systemically important operations at least temporarily. Finally, there is no fiscal backstop. Because of the deficiencies, the "too-big-to-fail" syndrome is still present. In view of the many legacy problems, this issue is critical. If the European Banking Union is to work, further reforms will be needed shortly.

Key Words: European Banking Union, European Central Bank, banking supervision, bank resolution, too-big-to-fail, sovereign debt

JEL Classifications: E58, F55, G21, G28, H63

1 Paper presented at the 42nd Economics Conference of the Austrian National Bank, Vienna May 12-13, 2014. I am grateful for very helpful comments from Christoph Engel, Paul Schempp, and Monika Ziolkowska. 


\section{Introduction}

The title of this paper alludes to an episode in 1897 when an eight-year-old girl had written a letter to the New York Sun asking: "Is there a Santa Claus?” and that newspaper published a full-page article under the headline "Yes, Virginia, there is a Santa Claus!" In listening to speeches or reading documents about the European Banking Union, I sometimes get the feeling that banking union is regarded as a kind of Santa Claus, which will make our wishes come true and solve all the problems of the euro area financial system. ${ }^{2}$

As an academic, I am always impressed by the ability of people in office to make succinct statements about problems and policies without explaining how the latter relate to the former. The Euro Area Summit Statement of June 29, 2012 affirms "that it is imperative to break the vicious circle between banks and sovereigns" and asks the Commission "to present proposals ... for a single supervisory mechanism” for banks, without explaining how the latter relates to the former. Nor does it explain what precisely is meant by "the vicious circle between banks and sovereigns".

I am also impressed by the ability of people in office to congratulate themselves on having come to an agreement or passed a law without worrying whether the agreement or the law will actually work and whether the new arrangements will solve the problems they are supposed to solve. The mere fact that a new arrangement has been put into place is treated as an achievement. In terms of the political process, this assessment may be appropriate, but, if the underlying problems are not addressed, the "achievement" may just be a way of wasting time and exposing us to further risks. If the policy makers have got the analysis wrong, we may all end up being the worse for it.

Right now, we are all congratulating ourselves on the steps that have been taken towards a European banking union, the Single Supervisory Mechanism and the Single Resolution Mechanism, together with the Banking Recovery and Resolution Directive, and previously the Capital Requirements Directive IV and Capital Requirements Regulation, as well as the Regulations establishing the European Supervisory Authorities. These are big steps forward. However, I have serious doubts whether they will substantially improve the future financial stability in Europe. I even have doubts whether they will suffice to take us out of the straights we are currently in. The reasons for these doubts will be laid out in this paper.

In Section 2 below, I begin with a brief overview over the problems of the euro area, the weakness of financial institutions that underlies these problems, and the governance problems in the euro area that have so far prevented a resolution of these problems. Subsequently, in Section 3, I discuss the possible role of banking union in dealing with the governance of fi-

2 Full revelation: I was a co-author of ASC (2012), which can be read in this vein. However, ASC (2012) and, subsequently, Sapir et al. (2012) are very clear about the need for a viable resolution regime; the discussion of the shortcomings of banking union in this paper follows directly from the analysis in those reports. 
nancial sector weakness. Major concerns are the remaining heterogeneities in supervision and from the lack of credibility of resolution mechanisms.

\section{What Are the Problems? Where Do They Come From? Why Are They Not Solved?}

\section{Fundamental Weaknesses}

European economies today suffer from three interrelated weaknesses:

- Economic growth is disappointingly low, not only in the periphery countries that pursue austerity policies but also in the core countries of the euro area.

- The levels of indebtedness of governments, nonfinancial companies and private households are very high and in most areas still rising.

- Financial institutions are weak, not only in the periphery countries but all over Europe.

These observations are reminiscent of the experience of Japan over the past two decades. In Europe as in Japan, some of the weaknesses may be due to fundamentals such as population aging and may therefore be unavoidable. However, some of them are also the result of flawed policies and should be mitigated by political reform. In the euro area, the problems are exacerbated by the fact that the arm's length relation between the central bank and the member states puts limits on the authorities' ability to deal with the banking problems effectively.

The poor growth performance is to a large extent due to the effects of overhanging debt and to the weakness of financial institutions. Because of excessive indebtedness, governments that were used to spending substantially more than they took in have been forced to retrench their activities, to raise taxes, or to obtain new funding through financial repression. All this harms economic growth. Weak financial institutions have reduced their lending, in particular to new firms that might provide impulses for innovation and growth. Some of this retrenchment has been a reaction to overexpansion before 2007, some of it has been imposed by financial repression, and some of it reflects the banks' own forbearance towards problem borrowers, motivated by a desire to avoid laying open the problems and taking the resulting losses on the books. $^{3}$

3 For extensive accounts of these issues, see ASC (2012), as well as Caprio and Klingebiel (1996, 1997) and Hoshi and Kashyap (2004, 2010). On financial repression and biases in bank lending in Europe, see Acharya and Steffen (2013) as well as the chapters by Bruni, Caminal et al., and Borges in Dermine (1990). 


\section{Banks and Sovereigns: A Vicious Circle?}

In this context, the formulation "vicious circle between banks and sovereigns" in the Euro Area Summit Statement of June 29, 2012 is not helpful. We have seen - and continue to see contagion effects from sovereigns to banks in some countries and from banks to sovereigns in others, but the picture of a doom loop between the two is more confusing than clarifying. The so-called "euro crisis" is in fact composed of different kinds of crises reflecting different failures of governance in the relation between financial institutions and governments. ${ }^{4}$

Some countries had old-fashioned sovereign debt crises that were caused by the inability of their politicians to set priorities and make hard choices so as to make ends meet. Examples are given by Greece, Portugal and, to a lesser extent, Italy. As documented by Reinhart and Rogoff (2009), this kind of crisis has a long tradition. Sovereign debt crises spill over into the financial system if the sovereigns in question have used their power to induce "their" banks into funding them and the sovereign's default imposes large losses on these banks. An example is given by Argentina in the 1990s and early 2000s. In the case of Greece, the 2012 haircut on sovereign debt necessitated substantial ESM contributions to recapitalizing Greek banks in order to save them from being insolvent.

Other countries had equally old-fashioned banking crises that were induced by boom-and-bust developments in real-estate markets. Examples are given by Ireland and Spain. This kind of crisis also has a long tradition. A little over twenty years ago, boom-and-bust developments in real-estate markets (and in lending to nonfinancial companies) were major causes of the banking crises in Japan, the United States, the Scandinavian countries, and Switzerland. ${ }^{5}$ When such developments occur, governments that find it necessary to support their financial institutions may see their debt levels rise dramatically so that the financial crisis in turn may induce a sovereign debt crisis. This was the experience of Ireland in 2010. Fear of such an experience was the reason why in 2012, Spain asked for the ESM to recapitalize its banks.

Except for the case of Spain, where the impact of the financial crisis on government deficits and debts in turn forced the government to increase its reliance on Spanish banks, there is little that is "loopy" about these developments. The two kinds of crises that I have described originate in quite different failures of governance. Conventional sovereign debt crises originate in failures of the political system; if these crises spill over into the financial sector, there is not much of a spillover back to the sovereign, which probably is unable to provide a bailout anyway. Conventional real-estate boom-and-bust and banking crises originate in failures of risk control in banks and in failures of prudential supervision over banks; if such a financial crisis spills over to the sovereign, a spillover back to the financial sector can occur if the initial financial crisis was localized, and the sovereign's difficulties affect the rest of the finan-

For a more extensive discussion of the interplay between the different crises, see Hellwig (2011).

See Hellwig (1994, 2009). In the United Kingdom, at the time, the costs of the downturn in real-estate markets and of the mortgage defaults were to some extent shifted to institutions in the insurance sector that had provided credit insurance to the building societies. 
cial system, a constellation that seems to have been relevant for Spain, where the financial crisis was concentrated in the cajas and their successor institutions, but not in Ireland, where the entire banking system seems to have been affected from the beginning.

\section{The Weakness of Financial Institutions is More Widespread}

The notion of a "vicious circle between banks and sovereigns" diverts attention away from the fact that the weakness of European financial institutions is not limited to countries where the sovereign has problems. This weakness also plagues countries such as France and Germany, where, so far at least, the sovereign has been able to bear the costs of the crisis. Quite generally, banks suffer from the weakness of their equity positions, from excessive reliance on shortterm funding through wholesale markets, and from an inability to earn profits in an environment that is characterized by excess capacity and intense competition. ${ }^{6}$

The events of 2011 are paradigmatic. With the results of the stress test of July 2011, the European Banking Authority also divulged information about the different banks' exposures to sovereign risks. Investors realized that a haircut of $50 \%$ or more on Greek sovereign debt, which they considered likely, ${ }^{7}$ might push some major European banks into insolvency because the equity of these banks was too small to absorb the impending losses. Consequently, investors withdrew their funding. When in September 2011 the need for a larger haircut was officially acknowledged, the pressures intensified. They were reinforced by the banks' own defensive measures, such as asset sales, which contributed to the downturn in asset prices and caused further losses in the banks' trading books. The October Summit's decision to raise capital requirements accelerated the downturn because the requirement was initially formulated in terms of ratios of equity to risk-weighted assets, and banks responded by further deleveraging. The process was only stopped when the ECB's Long-Term Refinancing Operation provided financial institutions - and markets - with an assurance that reliable funding would be available in large amounts.

The impact of the Greek debt haircut on banks outside of Greece should be seen as evidence of these banks' weakness, rather than a doom loop between sovereigns and banks. As of late 2010, the Belgian-French bank Dexia had equity equal to less than $2 \%$ of its assets. The bank did not have much Greek debt in its portfolio, but with so little equity, the haircut on Greek debt was enough to make the bank go under.

And fear of such an event will cause the wholesale short-term lenders to run. Dexia, which did not have a strong deposit base, was particularly dependent on wholesale lenders. Intense competition had forced this bank to engage in significant maturity transformation, using short-

$6 \quad$ For extensive discussions of these issues, see ASC (2012, 2014).

7 Investors greeted the announcement of the European Summit of July 21, 2011, which referred to voluntary private-sector involvement amounting to only $€ 37$ billion, with scorn. In a letter of August 3, 2011, written to the European Union's heads of state and government, the President of the European Commission indicated that he shared this skepticism. Publication of this letter accelerated the market implosion. 
term funding of long-term investments (the excess coverage needed as collateral on covered bonds) in order to improve its ability to compete on margins.

Dexia was perhaps an extreme case. ${ }^{8}$ Throughout these years, however, most large European banks have exhibited very low equity ratios and most large European banks have significantly relied on wholesale short-term funding. ${ }^{9}$ Many of them relied on funding from US money market funds to expand their activities in the United States, or more generally, US Dollar markets. This reliance - and the withdrawal of US money market funds - played a major role in the events of 2011 as well as the post-Lehman turmoil in 2008.

Consciousness of the vulnerability of financial institutions has shaped political reactions throughout. The sentence "This might be the next Lehman event" has been prominent in many discussions. I suspect that the breach of the no-bailout clause of the Maastricht Treaty in 2010 was at least partly motivated by a fear that the exposures of weak banks in France and Germany towards Greek debt might endanger these banks if there was a haircut. ${ }^{10}$ The ECB's Securities Markets Programs in 2010 and 2011, its Long-Term Refinancing Operation in 2011/2012, and last not least, its ECB’s announcement of Outright Monetary Transactions in September 2012 all seem to have been motivated by a sense that financial institutions were weak, financial markets were jittery, and financial instability was undermining the stability of the financial system and the macroeconomy.

\section{Current Stability Hides Underlying Problems}

Since September 2012, the European financial system seems to have become somewhat more stable. But this only means that we are no longer in an acute state of crisis. The underlying problems have not been resolved. Indeed, there are substantial reasons to be concerned about financial stability even now:

- Overall debt levels of nonfinancial actors have continued to go up, in particular, public debt levels. For debtors whose risks are considered to be small, the burden of this debt

The German bank Hypo Real Estate (HRE), which also did not have much of a deposit base, had pretty much the same experience, except that, in 2010, HRE had put more than $€ 170$ billion of problem assets into FMS Wertmanagement, a "bad bank" owned by the German government, so that the costs of the Greek haircut did not affect HRE. Because of their reliance on wholesale short-term funding, both Dexia and HRE had previously been particularly hard hit by the breakdown of money markets in September 2008.

$9 \quad$ As discussed by Brealey et al. (2010) and by Demirgüc-Kunt and Detragiache (2010), unweighted equity ratios have been significantly better indicators of bank robustness than risk-weighted equity ratios. From the late 1990s until 2007, unweighted equity ratios of large European banks went down significantly while risk-weighted equity ratios remained roughly the same. Even after correcting for differences in accounting rules, unweighted equity ratios in Europe tend to be significantly lower than for commercial banks in the United States. For an account of European developments, see ASC (2014).

10 As indicated by the numbers published after the 2011 stress tests, these exposures of French and German banks were subsequently much reduced. One may conjecture that some of the sales of these positions contributed to the increases in Cypriot banks' holdings of Greek debt, which occurred at about the same time and contributed greatly to the Cypriot banking crisis, which came in the aftermath of the Greek haircut of March 2012. 
may be light because nominal interest rates are small. However, for debtors whose risks are considered significant, private borrowers and sovereigns in the European periphery countries, the burden is significant. Moreover, there always is a risk that investors might become yet more pessimistic again and ask for even higher risk premia. Such increases in risk premia would further increase the burden on borrowers, which might end up confirming the pessimism of investors.

- Endeavors to improve the competitiveness of periphery countries may further increase the burden of their debt. Many commentators have suggested that periphery countries would easily regain competitiveness if only they were allowed to devalue. Such comments overlook the difficulty that devaluations raise the burden of debt denominated in foreign currencies. ${ }^{11}$ The same difficulty arises if the real exchange rate is lowered by domestic deflation, rather than a devaluation of the currency.

- Many banks are still weak, in particular in the periphery countries. Specifically, many banks still have little equity and rely on the ECB for substantial funding. Such banks tend to concentrate their investments in their own governments' debt and in tradable securities. Lending, in particular, lending to new firms, tends to come from banks that are better capitalized. ${ }^{12}$ As mentioned above, the diversion of funds away from lending to nonfinancial companies is a drag on the macroeconomy, in particular on economic growth.

- In contrast to their counterparts in the US, European banks' profits do not seem to have recovered yet. This is problematic because retaining earnings is the easiest way to rebuild equity. The ability to earn profits would also be the best means of restoring market confidence, enabling banks to reduce their reliance on ECB funding. There seem to be several reasons for this low profitability: First, banks may find it hard to earn significant profits because, following the crisis, banking capacity has not been much reduced and competition is still intense. The post-Lehman policy of bailing out most banks has prevented the adjustment of market structures that would otherwise have occurred. Second, the low-interest environment, while allowing for cheap funding, also reduces the rates banks can charge and may thus contribute to margins being low. If so, we face the dilemma that higher interest rates might seem to provide for better margins on new lending, but higher interest also raise the risks from high levels of outstanding debt.

- The low profitability of banks also raises questions about the skeletons that they may still have in their closets. For a few years now, we have seen European banks earning moderate profits in the first three quarters of the year and then showing sizeable losses

11 This problem is well known from the experience of Latin-American countries. Devaluation of the currency reduces the debt burden only if debt is denominated in the currency itself. On the inability to issue debt in the country's own currency, see Eichengreen and Hausmann (1999). 
in the last quarter. These losses seem to be driven by write-offs that are calibrated so that the overall result for the year is a black zero. While it is reassuring to see operating profits that enable them to pursue this strategy at all, one may wonder about the writeoffs that have not yet been taken. This concern is particularly relevant for positions in the bank book. I am not convinced that the asset prices that underlie the collateral valuations for German shipping loans or Irish or Spanish real-estate loans have been properly adjusted to the realities of the asset markets in question, to the extent that these markets are operating at all. I appreciate that asset markets are sometimes excessively volatile but I also know that some of the asset price declines that we have seen reflect a substantial asset overhang rather than any short-term market jitters. The shipping crisis, for example, will not disappear before the excess of prevailing capacity over demand at marginal-cost prices has been removed and shippers are again able to earn margins over average variable costs. This simple outcome of elementary microeconomic analysis has been neglected in all predictions from shippers and their bankers that I have seen. ${ }^{13}$

- Such concerns are also among the reasons why some banks still do not have much access to market funding and why for others such funding may become jittery again. As long as there are reasons to believe that a bank has not yet laid open all its losses, investors will also be concerned that the bank might be insolvent and will not be willing to fund it unless they expect to be bailed out, by taxpayers or by the central bank.

\section{Political Procrastination}

Some of these problems lie beyond the purview of banking regulation and banking supervision. However, the persistent weakness of European financial institutions also reflects shortcomings in the policies that have been followed since the crisis. In particular, as mentioned, the post-Lehman policy of bailing out most banks has prevented the adjustment of market structure that is necessary if the intensity of competition is to be reduced to a level where banks do not have to take unconscionable risks in order to survive because there is too much capacity in the market.

An important role was also played by regulatory forbearance towards the problematic assets that banks might have in their books. Closing one's eyes to the fact that performance of loan customers and collateral values may be questionable may seem a convenient way to avoid disagreeable and potentially costly interventions. However, more often than not, the problems

13 I made this prediction in 2009 when, as chair of the Lenkungsrat Unternehmensfinanzierung, I was involved with the applications of two major shipping companies for support from the German government's Wirtschaftsfonds Deutschland. According to the documents we got at the time, the shipping crisis would run in parallel to the business cycle and was therefore predicted to be over by 2012. In 2013, when the governments of Hamburg and Schleswig-Holstein proposed to raise their second-loss guarantees for the asset portfolio of HSH Nordbank, the prediction was that the crisis would be over by the end of 2014, even as excess capacity in shipping was still building up; see Hellwig (2013). 
do not disappear on their own and the delay is likely to make the intervention that much costlier when it becomes unavoidable. ${ }^{14}$

There are several reasons for these shortcomings. First, intervention is always costly. If a bank is in serious trouble, a recapitalization costs money, and resolution may bring turmoil to the economy. Governments and supervisors must also fear public scandal as people ask why the problems have been allowed to arise and why they have not been dealt with before. Kicking the can down the road and hoping for the best may therefore seem more attractive. If the banks in question are extremely large or if there are very many of them, the problem may also be too big to handle because the public funds needed to avert the negative fallout from the crisis may exceed the government's fiscal capacity. Thus, when the Swedish government intervened very promptly to clean up the banking system in 1992, it lacked the fiscal capacity to also smooth the recession (which however was short, thanks to the cleanup of the banking sector and to the trade effects of currency devaluation).

Second, banks are political. This is true in particular of public banks like the German Landesbanken, whose lending policies are often tailored to the interests of the regional governments that own them. More generally, political authorities tend to think of banks as institutions that should serve to fund their policies, promoting the government's industrial policies or simply funding the government itself. ${ }^{15}$ In some cases, the government's industrial policies have been focused on the banks themselves, using financial institutions that attract funds from the rest of the world and invest funds in the rest of the world as a tool for creating a fair number of highpaying jobs very quickly. ${ }^{16}$ With such a policy stance, they are not likely to engage in active interventions that would force the banks to lay open their losses and either recapitalize or retrench their activities.

\section{Cross-Border Externalities in the European Union and the Euro Area}

European integration also plays a role. In the European Union, and in particular in the euro area, national policies towards banks are fraught with cross-border externalities. If a bank's activities in all countries of the European Union, indeed, in the European Economic Area, are regulated and supervised under the home country principle, any bank's customers and counterparties depend on the home country's authorities' doing a good job to ensure the safety and soundness of their banks. If the home country's authorities are interested in using the banking sector as a source of economic growth however, they may be willing to compromise on supervisory standards.

14 On this point, see ASC (2012), as well as Caprio and Klingebiel (1996, 1997).

15 For a more detailed discussion, see Chapter 12 in Admati and Hellwig (2013).

16 This has been the experience of Iceland, Ireland, and Cyprus. More traditional financial centers, such as the United Kingdom or Switzerland have also seen economic growth fuelled by promoting the financial sector as an export industry but their dependence on this sector has been somewhat less pronounced. 
Such laxness played a role in Icelandic banks growing by acquiring deposits from customers in the United Kingdom and the Netherlands. In the crisis, the costs of bailing out these depositors were borne by the United Kingdom and the Netherlands rather than the home country of the failing banks. ${ }^{17}$ In Ireland, a promise of "light-touch" regulation and supervision was a means of attracting financial business to Ireland, and funds from abroad fuelled the Irish realestate bubble. In the crisis, the Irish government ended up bailing out the senior unsecured creditors, many of them banks from other European countries, but from what I have been told, this decision was anything but a foregone conclusion and involved much pressure from European institutions and from other member states.

In the case of Ireland, the decision to bail out the senior unsecured creditors required the country to seek help from the EFSF. The problem of cross-border externalities was thus shifted from the level of cross-border externalities for investors to the level of cross-border externalities for other member states and European institutions. The Spanish request in 2012 for ESM funding of bank recapitalization exhibits the same kind of externality. In the mid-2000s, national authorities in Spain failed to interfere with banks fuelling a real-estate bubble. Ultimately, this failure was at the origin of the need for ESM support in 2012.

In the summer of 2012, the other member states of the euro area had a substantial interest in the matter. Markets were dominated by a sense of panic that threatened the funding of financial institutions all over Europe, as well as the funding of the Spanish sovereign. There were substantial fears that the Spanish authorities had been less than incisive in dealing with the problems of the cajas and their successors and that the hidden losses might exceed the sovereign's capacity to bail out the banks' creditors.

As in 2011, these developments put the ECB on the spot. Financial stability is not explicitly mentioned in the Treaty as an objective of ECB policy, but banks are an important part of the monetary system, and a banking crisis poses a serious threat to monetary stability. In Spain in 2012, markets were again jittery and the monetary system was under pressure. Even depositors, usually the most patient of investors, were moving their funds out of the country. ${ }^{18}$

17 Remarkably, the EFTA Court accepted the argument of the Icelandic government by which it was legitimate to transfer Icelandic deposits but not foreign deposits from the failing banks to the successor institutions so that the government's bailout measures benefited only domestic depositors.

18 In this context, it is helpful to go back to the simple quantity theory approach of Friedman and Schwartz (1963). For the years 1929 - 1933 in the United States, they observed that, while the monetary base grew by $15 \%$, the quantity of money (M1) contracted by $33 \%$ because the banking crises induced behavioral changes among depositors as well as banks, raising both the currency-deposit ratio and the reservedeposit ratio. In their assessment, monetary policy in these years was "contractionary" because the expansion of the monetary base failed to compensate for the implosion of deposits. Bernanke (1983) focuses on the credit channel for monetary transmission, arguing that bank closures caused the loss of information capital that had been accumulated in banks' lending to firms and disappeared when the banks went under. Despite the differences in their accounts of the transmission mechanism, the different authors agree that commercial banks are an essential part of the monetary transmission mechanism and that a breakdown of banking calls for additional measures of the central bank. 


\section{Putting the ECB on the Spot}

Throughout these years, with unorthodox measures in 2008, the Securities Markets Program in 2010 and 2011, the Long-Term Refinancing Operation in 2011/2012, the announcement of Outright Monetary Transactions in 2012, the ECB has repeatedly stepped in to preserve financial and monetary stability by counteracting the effects of financial sector weaknesses. It could do so because it was in a unique position to act without regard to funding constraints.

There are, however, substantial reasons to believe that the Long-Term Refinancing Operation benefited not only healthy banks but also banks whose health was doubtful, perhaps even banks that would have been insolvent if they had been forced to uncover their hidden losses. In fact, reliance on ECB support was most important for those banks that had the weakest capital positions and the greatest difficulties in obtaining market funding. ${ }^{19}$

A decade ago, the various Memoranda of Understanding (MoU) for how to deal with banks in difficulties provided for a clear division of tasks: Solvency problems were to be covered by the national treasuries, liquidity problems of individual institutions by the national central banks, and liquidity problems of the entire system by the ECB. ${ }^{20}$ If supervisory forbearance at the national level enables de facto insolvent banks to benefit from ECB funding, these principles are violated, and there is little that the ECB can do about it.

The very strength of the ECB is a source of weakness. If the ECB is serious about monetary stability, it is forced to follow a policy that effectively supports the financial system, including those institutions that should be resolved but are not. Given the knowledge that the ECB will support the system anyway, the pressure on national governments and national supervisors to clean up their banking systems is that much weaker. Some politicians may in fact have come to understand that the very weakness of their banks gives them an indirect access to the printing press. After all, in the case of the Long-Term Refinancing Operation, a large part of the money that banks got from the ECB was lent to the banks' own governments. ${ }^{21}$

The division of tasks that was enshrined in those MoUs was naïve. Acting as a lender of the last resort has always been an important role of central banks, and this role has always involved the provision of implicit subsidies to the banks that received the support. ${ }^{22}$ One of the more successful central banking operations of recent decades was the 1990 turnaround of US monetary policy. When the large money center banks in the US were in a state of crisis, the Federal Reserve lowered short-term interest rates quite drastically and allowed the troubled banks to rebuild their equity by playing the yield curve for years. However, apart from the implicit transfer of seigniorage from the central bank to the commercial banks, this policy had the drawback that, as seen in 1994, commercial banks became very vulnerable to interest rate

19 Acharya and Steffen (2013).

20 For a critical discussion of this arrangement, see Hellwig (2007).

21 Acharya and Steffen (2013).

22 For a systematic discussion, see Hellwig (2014), with references to Goodhart (1988). 
shocks and, more importantly, that they came to believe in the "Greenspan put" as protection against any risks that they might run.

In the European context, the availability of ECB support has contributed to the maintenance of market structures and the failure to close unprofitable banks. Here again, national government policies involve significant cross-border externalities. Countries that expand their financial sectors as a means of industrial policy put pressure on bank margins Europe-wide. So do countries that provide explicit or implicit guarantees to some or all of their banks. The fact that banks like Dexia and HRE had to engage in wholesale short-term funding for the excess of their portfolios over their covered-bond issues must in part be ascribed to the German legal "reform" of 2005, which reduced barriers to entry into covered-bond markets, a measure that allowed the Landesbanken to much expand their activities in this segment. While the crisis has induced some retrenchment, many of the basic structures are still in place, ready to expand again when the occasion arises.

Maintenance of market structures with excess capacities through explicit or implicit guarantees and other subsidies should in principle be prevented by the European Commission's state aid control. However, as shown by the decade-long fight over the public guarantees for the Landesbanken, in the area of banking, where significant political stakes are involved, state aid control is weak and slow. ${ }^{23}$ With the crisis, state aid control has become even weaker because any government that wants to maintain a bank will simply claim that, if the bank is resolved, financial stability will suffer. ${ }^{24}$ Such a claim may be dubious but the rules for state aid to financial institutions that have been put in place since 2008 allow for financial stability considerations, and it is not easy for the Commission to question whether the bank really poses a threat to financial stability.

23 In the end, the 2001agreement between Commissioner Monti and the German government enabled the European Commission to establish the prohibition of guarantees for public banks as a form of illicit state aid without having to go to court over the matter. For details, see the European Commission's Press Release IP/02/343 01/03/2002 of February 28, 2002, on the implementation of the understanding, available at http://europa.eu/rapid/press-release_IP-02-343_en.htm?locale=en. Under the agreement, the Commission accepted a four-year transition period, which public banks used to raise significant additional funding under government guarantees. Wasteful investment of the funds was a major reason for their difficulties in the crisis, from German banks Sachsen LB and West LB to Austrian Hypo Alpe Adria.

24 See for example the case made in 2013 by the German government to justify renewed support for HSH Nordbank. See 


\section{Will Banking Union Solve the Problems?}

\section{The Decision of the Euro Area Summit of June 2012}

The many cross-border externalities in financial-sector regulation suggest that, in a monetary union, a system with purely national control over financial institutions may not be viable. ${ }^{25}$ Given the importance of judgment in supervisory decisions, the mere harmonization of the legal framework through regulations and directives may not be enough to eliminate moral hazard and negative cross-border externalities. Recognition of these problems led many to argue for the creation of a European banking union. ${ }^{26}$

However, the different participants in the June 2012 decision had different interests and were pursuing different objectives. The European institutions saw banking union as a further deepening of European integration and hoped that this would overcome the problems. In particular, the European Commission was pushing for a European deposit insurance system in order to stop the outflow of deposits from countries that were perceived to be at risk. The European Central Bank was pushing for a single supervisory mechanism in order to get out of the straightjacket of having to tailor its monetary policy to the needs of financial stability that were insufficiently taken into account by national authorities. Spain was pushing for ESM support for recapitalizing its banks. Germany, it seems, was pushing for European control as a prerequisite to making ESM funds available to Spanish banks, perhaps without appreciating that this might also involve European control over German banks.

Developments since then have been much influenced by these differences in interests and objectives. They have also been influenced by differences in legislative procedures for the different components of the banking union. In the euro area, supervision will be handled by the Single Supervisory Mechanism (SSM), which is created by a Regulation of the Council under the auspices of Art. 127 (6) TFEU. Resolution in the euro area will be handled by the Single Resolution Mechanism (SRM), which is created by an EU Regulation under the auspices of Art. 114 TFEU, and will be funded by a Resolution Fund, which is created by an intergovernmental agreement with the approval of the Commission and the Parliament. In the European Union as a whole, procedures for dealing with banks in difficulties will be governed by the Bank Recovery and Resolution Directive (BRRD), which still needs to be transposed into national laws. New rules for deposit insurance will also be governed by a directive. I am wondering to what extent the differences in legal foundations may end up affecting the viability of the overall system.

25 Some of the problems with the previous arrangement were pointed out in Hellwig (2007). ASC (2012) suggests that, even for the European Union as a whole, with the internal market in banking, a purely national control over financial institutions, subject to European regulations and directives, is problematic.

26 Brussels-based Bruegel provided some of the key arguments and ideas. See, in particular, Pisani-Ferry et al. (2012). 


\section{Supervision: Heterogeneity of National Laws and Judicial Review}

An important innovation of Council Regulation (EU) No 1024/2013, which creates the Single Supervisory Mechanism, concerns the status of supervisory authorities. According to Art. 19 of the Regulation, the ECB and the competent national authorities shall be independent in their supervisory activities. This is a welcome change from the status quo ante, which had at least some supervisory authorities subordinated to their respective governments. ${ }^{27}$ This change provides some hope that supervisory decisions will become less influenced by the national governments’ political interests.

As a practical matter, the shift to the SSM is unlikely to pose major problems. But even here, there are pitfalls. One pitfall concerns the heterogeneity of laws and jurisdictions. One might think that, in principle, there is just one set of rules for the entire European Union. However, only regulations are directly applicable. Much of the relevant EU law takes the form of directives, which are not directly applicable but require transposition into national law. Art. 4 (3) of the Regulation stipulates that "the ECB shall apply all relevant Union law, and where this Union law is composed of Directives, the national legislation transposing those Directives.”28

This means that the ECB will have to apply 17 or more different laws. This heterogeneity raises issues of consistency across member states. It also raises questions about the roles of the Court of Justice of the European Union (CJEU) and the national courts in judicial review.

According to Recital 60 of the Regulation, judicial review is assigned to the CJEU, which will assess "the legality of acts ... of the ECB, other than recommendations and opinions, intended to produce legal effects vis-à-vis third parties.” This formulation is taken almost verbatim from Art. 263 TFEU, and the recital refers to this article. Even so, I am wondering how this will work for decisions of the ECB that are taken under national laws even when these laws implement European directives. Is the CJEU really qualified for this task? And does the reference to the Treaty provide a sufficient legal basis for this assignment? Presumably, the word "legality" in the recital and in the Treaty refers to the legal norms of the European Union, not to the legal norms of the member states. But the laws implementing the European directives are legal norms of the member states.

In this context, I note that the different courts have different traditions of judicial review of administrative decisions. For example, in the area of competition policy, the CJEU has traditionally given the European Commission wide scope for the exercise of judgment in the assessment of facts. The court has typically refrained from making a judgment of its own about the validity of the Commission's conclusions and merely asked whether the evidence and the

27 A decade earlier, this had been a matter of dispute in the discussion about the European Constitution. The ECB would have liked the Constitution to stipulate independence of central banks in all their activities, not only in matters of monetary policy. The Constitutional Convention did not accept the ECB's proposal. See European Commission (2013).

28 The question of how to deal with legal norms that are codified at the European level in the form of Directives was raised by Sapir et al. (2012) in a comment on the European Commission's first draft of the Regulation, which did not address the problem at all. 
reasoning that the Commission had put forward were sufficient to support its decisions under the relevant legal norms. ${ }^{29}$

By contrast, some of the national judiciaries are more restrictive. In Germany, for example, administrative courts draw the lines for the exercise of judgment very narrowly and require the administrative authority to provide material proof that its decision is derived from the legal norms as they apply to the facts on hand. Underlying this practice is the consideration that, under the democracy mandate of the Basic Law, i.e., the constitution, any decision by an administrative authority should in principle be derived, at least indirectly, from choices taken by the representatives of the voters.

In the context of the SSM, the difference in judicial attitudes to the exercise of judgment by an administrative authority is important because much supervisory activity does involve such an exercise of judgment, judgment about the quality of assets that a bank holds, about the riskiness of a bank's strategy and even the professional quality of its management. Indeed, this exercise of judgment is where the governance of supervision matters most and where the shift to a Single Supervisory Mechanism may be presumed to have the biggest impact.

One may hope that these issues will never arise because nobody goes to court. However, even if nobody goes to court, the mere threat that affected parties might do so can have an effect. Consider the public discussions that we have had after the crisis about supervisory laxness in the preceding years, for example, the German supervisor's acceptance of practices whereby banks created special purpose vehicles to hold mortgage-backed (and other) securities without backing them by equity, funding them through asset-backed commercial paper and providing the creditors with liquidity guarantees for these vehicles. These vehicles and the commitments that banks made to them played a major role in the buildup of risks before the crisis, and they caused substantial losses. The German supervisor has maintained that they were aware of the risks but, under the letter of the prevailing law and given the strictness of German administrative courts, they did not see any room for prohibiting these practices. Other supervisors were more restrictive and disallowed such practices.

Would this have played out any differently if the ECB had already been in charge? Or would the ECB have issued an injunction against the use of special purpose vehicles for holding investments off-balance-sheet? If so, how would the decision have been treated by a German administrative court? Or, if the appeal to a German administrative court was precluded by Recital 60 of the SSM Regulation, how would the German Constitutional Court have looked

29 For example, in the famous Airtours-First Choice merger case of 2002, the Court overturned the Commission's decision on the grounds that the Commission assessed the merger as being conducive to more collusion among the remaining suppliers in the market without giving a coherent argument as to why this would be so. The plaintiffs had argued that, according to standard economic theory, a variety of objective features of the markets and products involved would make collusion quite difficult. In the same year, the Commission's prohibition of the Schneider-Legrand merger was turned down on the grounds that the Commission had failed to provide the empirical data needed to establish its case. 
upon the denial of due process against an administrative measure taken under German law? ${ }^{30}$ For after all, the law on banking regulation that implements the European directives is a national law!

Such problems would of course be removed once and for all if all the relevant legal norms were brought into the Regulation. I expect that, at some point, we will get there, and I hope that, in the intervening time, the uncertainties and impracticalities associated with the heterogeneity of national laws will not be too costly.

\section{Dealing with Banks in Difficulties: Recovery and Resolution Procedures}

The most careful and most professional supervisor is helpless if there is no practical way of dealing with problem banks. ${ }^{31}$ The Lehman experience has made us all very sensitive about this issue. We learnt that “Too Big To Fail” is not a myth: Letting a bank fail can indeed have catastrophic consequences, and can be much costlier than a bailout.

Since the Lehman crisis, authorities worldwide have been torn back and forth between two concerns, on the one hand, the desire to avoid a repetition of the post-Lehman panic, on the other hand, the desire to develop procedures for dealing with problem banks that would avoid the kind of tsunami that we saw in September 2008. The BRRD and SRM are part of this program.

However, I sometimes wonder whether improvements in resolution procedures are really meant to make resolution viable, or whether they are meant as placebos to avert political protest against a regime in which the financial industry has blackmailed taxpayers into providing support, for fear that otherwise things might get much worse. Many of the reforms that have been instituted are likely to prove impractical if we get into another crisis.

In the rhetoric accompanying such legislation, the proponents never show how the new legislation would have worked in the Lehman crisis if it had been available then. If we want to avoid a repetition, however, it is imperative that we recall precisely those problems and see what can be done about them. Actually, the post-Lehman experience was different in different countries:

30 Such constitutional concerns can also be raised about Art. 13 of the SSM Regulation, which relates to the authorization by a judicial authority of an on-site inspection if such authorization is required under national law and asserts that in such cases the national judiciary shall control that the measures taken in this context are not taken wilfully, but shall not decide on the lawfulness of the measures; lawfulness is to be assessed by the European Court of Justice. If the conditions for such inspections are specified in the national law, this article transfers jurisdiction over the application of national law out of the domain of the national judiciary.

31 This point is very much emphasized in ASC (2012) and Sapir et al. (2012). 
- From the perspective of the United States, the post-Lehman experience is dominated by the implosion of money market funds. ${ }^{32}$ The Lehman Brothers bankruptcy caused Reserve Primary to break the buck. News of this event triggered a run on Reserve Primary and on other money market funds. As a result, all money market funds withdrew funding from banks, in particular US investment banks, which the Lehman Brothers bankruptcy had made to appear more risky anyway. As banks all over the world were scrambling for cash, they tried to sell assets, which sent asset prices into a tailspin.

- In the United Kingdom, the post-Lehman experience is dominated by the disappearance of a key market maker in derivatives markets. Maintenance of systemic functions was deemed to be impossible because there was no legal basis for doing so and because there was no funding. Lehman Brothers, London, was a legally independent subsidiary, but the different subsidiaries in different countries had integrated cash management. When authorities in the UK took over the bank, they found that there was no cash because all cash had been sent to New York at the previous close of business.

Three important difficulties emerge:

- As different legal entities belonging to the same group go into different bankruptcy/orderly liquidation/recovery and resolution procedures, each one in the country where it is located, the integrity of corporate operations is destroyed, and this can destroy the viability of systemically important functions. In the case of Lehman Brothers, this was most noticeable for their integrated cash management. Potentially even more important are integrated IT systems, where the entry of multiple resolution authorities in multiple places raises the question of what is the legal or contractual basis, and what are the rules and the pricing, for continued joint use of these systems which is essential for the maintenance of systemically important operations.

- Any maintenance of systemically important operations requires funding. Without funding, such operations cannot be maintained. Market funding, however, is likely to vanish unless creditors are given guarantees that they will not be harmed.

- Systemic effects are not limited to domino effects from the breakdown of existing contracts. The disappearance of contractual partners on whose availability one had counted or the implosion of asset prices from fire sales may be much more important.

32 The AIG episode occurred at the same time but, as far as I can tell, this episode was not directly related to the Lehman Brothers bankruptcy. For a more detailed account, see Admati and Hellwig (2013), chapter 5, and the references given there, in particular FCIC (2011). 
- In thinking about the maintenance of systemic functions, it is worth recalling that Lehman Brothers had hundreds if not thousands of subsidiaries. ${ }^{33}$ If such subsidiaries act in an integrated fashion, managing the system is a daunting task even for those who know it. For the authorities replacing incumbent managing, the task is that much more difficult.

\section{Dealing with Banks in Difficulties: Banks with Systemically Important Subsidiaries in Different Countries}

On the key issue of how to maintain systemic functions of a bank with systemically important operations in different countries, progress since 2008 has been miniscule. Multiple-point entry, i.e., the entry of different authorities of different countries into the legally independent units located there, is still the prevailing legal rule. The United States and the United Kingdom have been negotiating about single-entry procedures, but they seem to be thinking more of recovery than resolution, and the issue of loss sharing in resolution has not been settled. The living will that Deutsche Bank has submitted to the Fed and FDIC proposes that US authorities should let the German authorities deal with any crisis situation. However, the US authorities do not seem to be convinced by this proposal. Their recent ruling that foreign banks must organize their US subsidiaries so that US equity and liquidity requirements can be imposed indicates that they are thinking of ring-fencing the US operations of foreign banks. Given the experience of ring-fencing by European supervisors, e.g., the restrictions that Bafin imposed on Unicredit Germany in 2012, one can hardly blame them.

Directive 2014/59/EU of the European Parliament and of the Council establishing a framework for the recovery and resolution of credit institutions and investment firms (BRRD) provides for some coordination within the college of resolution authorities. However this coordination can hardly substitute for the organizational integration of operations in the bank as a going concern. This basic problem remains unsolved. Therefore I predict that, if a bank like Barclays, BNP Paribas or Deutsche Bank, with systemically important functions in different countries, were to get into trouble, authorities would be unwilling to enter into a recovery and resolution procedure, i.e., we would continue the post-Lehman practice of bailing banks out.

The SRM provides for a centralized procedure with single-entry resolution for large banks. However the procedure is complex and provides much scope for participants to veto decisions they do not like. For institutions of the importance and complexity of BNP Paribas or Deutsche Bank, the mechanism will therefore be no more practical and trustworthy than the provisions of the BRRD. Indeed, since the US and the UK do not participate in the SRM, a major part of the multiple-entry problem is not even addressed.

33 Herring and Carasi (2010) mention 433 majority owned subsidiaries, Miller and Horowitz (2012) speak about 8000 subsidiaries in over 40 countries. 


\section{Dealing with Banks in Difficulties: The Need for Interim Funding}

Another shortcoming of the BRRD is its naiveté about the time needed for resolution and the need for funding during this time. Recitals 103 - 105 note that such funding may be needed and assert that it should be provided by resolution funds under the control of resolution authorities. Given the numbers involved and given past experience, this is unrealistic.

The Single Resolution Fund for the SRM is targeted for a level of $€ 55$ billion, the German Bank Restructuring Fund for a level of $€ 70$ billion, to be reached after many years. These numbers are much too small to ensure interim funding of institutions like Deutsche Bank or BNP Paribas, with liabilities on the order of $€ 2$ trillion, a large part of which is wholesale and short-term, i.e., easy to discontinue if counterparties get nervous. Promises of support from a fund with $€ 55$ or $€ 70$ billion are not going to stop a run if creditors with claims amounting to $€ 1$ trillion or more are worried about a bank. In fact, this is not just a problem for banks with trillion-euro balance sheets. The problem also arises with banks like Commerzbank or the Landesbanken, whose liabilities amount to several hundreds of billions of euros.

Discussions about the funding of recovery and resolution procedures usually pay too little attention to the distinction between the need to fund operations as long as they are ongoing and the need to allocate or to absorb ultimate losses. Resolution or restructuring fund target levels in the double-digit-billion range may be sufficient to absorb ultimate losses, but they stand in no realistic relation to the interim funding that is needed to keep systemically important operations going, at least for a while. The SRM will be able to borrow from the ESM but the numbers that have been given there, like those for restructuring or resolution funds, stand in no realistic relation to what is needed to maintain interim funding.

In ordinary insolvency law, the problem of interim funding for ongoing operations is usually handled by giving new creditors, i.e., creditors who come in after the firm has entered into insolvency proceedings, priority over previous creditors. For nonfinancial companies, this arrangement is viable, at least for a while, because the funds needed to maintain ongoing operations tend to be small relative to the firm's assets.

For a bank, this arrangement is problematic, which is precisely why we need a procedure that is different from ordinary insolvency procedures. Banks have a lot of short-term funding, through wholesale loans as well as deposits. If these claims on the bank are frozen, there may be substantial systemic damage. For example, a money market fund whose claims are frozen may be run upon, as Reserve Primary was after the Lehman Brothers bankruptcy. As we saw in September 2008, such runs on money market funds may endanger the entire system of short-term wholesale bank funding. If the short-term claims on the bank are not frozen, maintenance of bank funding requires that these claims be renewed or replaced. For a bank in a resolution procedure, such renewal or replacement of funds will not be forthcoming unless the lenders are given public guarantees. Priority over previously incurred liabilities of the 
bank is not sufficient because the amount of such funding is large in relation to the bank's assets so that, without public guarantees, there is a risk for the lenders.

Nor is it sufficient to exempt secured claims and very short-term inter-institution claims from bail-in, as the BRRD does. For lenders with secured claims, there is always a question whether the collateral is sufficient. With Bear Stearns and Lehman Brothers, doubt about the collateral caused the "repo runs" on these institutions. Such doubts can be caused by concerns of the collateral value itself. They can also be caused by concerns about re-hypothecation, i.e., the fact that the same securities are used as collateral for several loans. If such doubts cause lenders to increase collateral haircuts, encumbrance of the bank's assets by collateralization is exacerbated - and the ability to maintain funding further endangered.

Exemptions of very short-term inter-institution claims are more clearcut but even so these claims are vulnerable to the risk that the lenders themselves might be run upon, as happened to US money market funds after the Lehman Brothers bankruptcy.

The problem of interim funding can be solved by providing resolution authorities with public guarantees or by allowing these authorities to borrow from the public purse. Under the DoddFrank Act in the United States, the FDIC can simply borrow from the Treasury. ${ }^{34}$ Under the BRRD, however, the problem is not addressed. An important question will be whether national legislation will go beyond the BRRD and provide resolution authorities with sufficient access to interim funding or with sufficient backstops so that they can give the guarantees that are needed to maintain the systemically important functions of a bank at least for a while.

\section{Dealing with Banks in Difficulties: Asset Valuation and Bail-Ins}

To some extent, the neglect of interim funding problems seems to be due to the fact that the BRRD has a very optimistic vision of how resolution is carried out: Some Friday, the supervisory authority determines that a bank is likely to fail. It calls for the resolution authority to take over. The resolution authority obtains an independent valuation of the bank's assets and liabilities. On the basis of that valuation, it writes down the bank's equity, and it writes down the bank's liabilities or converts them into equity, following the hierarchy of claims under insolvency law. If all this is done over the weekend, then by Monday the bank is again well capitalized, and the resolution authority is in a good position to move forward. Perhaps it has already used the weekend to sell the business or to set up a bridge bank.

This vision is too optimistic. First, asset valuation is problematic. At the time of entry of the resolution authority into the bank, the bank's prospects and the value of its assets are highly uncertain. The uncertainty about the value of the assets may itself be a key factor in the difficulties of the bank.

34 The German Bank Restructuring Act of 2010 also allows for borrowing from the public purse, but the scale of the restructuring fund is by an order of magnitude smaller than interim needs for funding and/or guarantees. 
What was the value of the United States S\&L's assets in 1990? What was the value of assets and derivatives in the books of Long-Term Capital Management in September 1998? What was the value of mortgages and mortgage-backed securities in the books of Lehman Brothers or AIG in September 2008? What was the value of real-estate loans in the books of Spanish cajas in 2012? The answers to these questions are highly sensitive to the chosen principles for valuation. They are also a matter of judgment as to how long the current crisis is going to last. Finally they depend on how quickly the assets in question have to be liquidated. In the case of the US S\&Ls, estimates of the costs to deposit insurance institutions were on the order of $\$$ 600 billion to $\$ 800$ billion dollars around 1990; in the end, these costs came to \$ 153 billion. ${ }^{35}$ In the case of LTCM, the Federal Reserve feared that a bankruptcy followed by a quick liquidation of assets and derivatives might trigger an asset price implosion. Therefore, it put pressure on other banks to provide interim funding for a slow liquidation. The strategy was successful so that the banks involved did not actually lose money on the interim funding.

The directive does allow for a preliminary valuation as a basis for bail-ins, but it also asks for an ex post valuation to be performed "as soon as possible”. In the case of the S\&Ls, "as soon as possible” would have been ten years later, which probably is not what is meant by the BRRD. A reliable final loss allocation however does require a lot of time - unless the authorities are willing to speed the procedure up, if necessary by selling assets prematurely.

Second, resolution involves more than a valuation of assets and a recapitalization on the basis of writedowns and debt-to-equity conversions. Key questions concern the correction of past management mistakes, the search for new owners, the decision as to which assets should be part of the bank as a going concern and which ones should be separated and wound down. Answering these questions takes time. During this time, uncertainty about the future of the bank and about the value of its assets encumbers the bail-in mechanism and endangers funding - even from creditors whose claims are not subject to bail-in.

\section{Dealing with Banks in Difficulties: Fiscal Backstops}

Most legal reforms of recovery and resolution procedures that have been introduced since 2008 have come with a promise that never again will taxpayers have to foot the bill for bank bailouts. The Dodd-Frank Act in the United States is one example, the German Bank Restructuring Act of 2010 another. The BRRD follows the same principle, albeit somewhat less stringently.

These promises are either naïve or cynical. If systemically important banks are in trouble and the choice is whether to let them go under or to support them, the answer will be "We do not want to have another Lehman experience!” This is the lesson learnt in 2008, and in many respects it is the right lesson. The costs of the Lehman Brothers bankruptcy and the financial turmoil it induced far outweighed whatever the fiscal costs of a bailout might have been. 
In such a crisis situation, some public funds are needed, at least to maintain interim funding of systemically important operations. Putting in public funds, even temporarily, puts taxpayers at risk. If the bank is insolvent, somebody has to pay for the difference between liabilities and assets.

Ostensibly, this is what restructuring or resolution funds and industry levies are there for. However, in a crisis that affects the entire industry, these funds are likely to be too small to cover the losses. Even if industry levies are increased ex post, there is no guarantee that it will be sufficient to cover losses. In a crisis situation, the capacity of surviving industry members to contribute to such a levy will be severely limited. ${ }^{36}$ Even if the charges are spread over time, there is still a substantial burden, which affects the banks just as an excess of debt overhang would.

For example, in the S\&L crisis of the 1980s in the United States, the industry was in such difficulties that it could not bear the costs of the crisis; the Federal Savings and Loans Insurance Corporation (FSLIC) became insolvent and was merged with the FDIC. Out of \$153 billion of losses, in the end, the industry paid \$29 billion and taxpayers \$124 billion. If a comparable systemic crisis was to happen today, in the US under the Dodd-Frank Act or in Germany under Bank Restructuring Act, the experience would be repeated. This would be a breach of the promises with which these laws were introduced but at least it would work.

The S\&L example may be seen as atypical in that most S\&L funding in the United States had come in the form of deposits, which were federally insured. Thus there was little room for clawbacks or bail-ins of creditors. One may therefore hope that ultimate losses in bank resolution will be smaller if more creditors are bailed in, i.e., if more creditors are forced to participate in losses as they would have to do if the bank entered a bankruptcy or insolvency procedure.

On this point, the BRRD is not reassuring. The BRRD contains important statutory exceptions from bail-ins: Covered deposits, secured liabilities and derivatives, and inter-institution liabilities with maturities of less than seven days. The authorities can also grant additional exceptions on the spot if they deem such exceptions to be necessary to forestall contagion or other forms of systemic risk. To ensure that, in spite of these exceptions, there is at least some debt that can be bailed in, the directive requires that exempt liabilities amount to no more than ninety-two percent of a bank's funding. Loss absorption from equity and bail-in-able debt can be as little as eight percent of total assets.

The Lehman crisis and the post-Lehman bailouts have created a strong lobby against any creditor liability. Forcing creditors to bear losses, we are told, entails a danger of systemic risks from domino effects, as those creditors themselves may be too weak to absorb those losses, or as the realization that creditor liability must be taken seriously hurts funding condi-

36 In any event, it should be clear that the levy itself is a kind of tax, supporting institutions in difficulties at the expense of institutions that have not seen risks materialize. 
tions of other banks. This thinking has dominated public discussion and public policy for quite a while, including initial discussions about the Cypriot crisis. The Cypriot crisis and the treatment of SNS Reaal provided for some change, but as yet I am not convinced that these events determine the new paradigm.

Indeed, given the uncertainties about how systemically important functions are to be maintained and funded, I expect that, in a clutch, most governments will decide that it is better to avoid a resolution procedure altogether. Back to “Too Big To Fail”!

The BRRD leaves room for such avoidance by allowing recapitalizations of banks even before they enter into the recovery and resolution procedure. Such a recapitalization presumes that the requisite funding is available, as is the case in countries with strong fiscal positions. If the requisite funding is not available, the recovery and resolution procedure may still be avoided if the authorities exert forbearance and procrastination as they have done in the past. Without a fiscal backstop at the European level, I am not convinced that, on this account, the SSM will change so much.

\section{Dealing With Banks in Difficulties: Legacy Risks and Fiscal Responsibility}

Ironically, the legislation for banking union took so long that the concrete problem that was of concern to the June 2012 Summit, namely the recapitalization of Spanish banks, has been dealt with even before the legislation had been passed, let alone entered into force. In 2012/2013 ESM provided some $€ 41$ billion for the recapitalization of Spanish banks, with conditionality for restructuring of the industry; by now, the Spanish government has declared that no new assistance will be needed; the funds that were provided will be repaid over a period of more than a decade. However, in this process, the Spanish government remained (and remains) liable as the ESM funds did not go directly to the banks but the Spanish government's recapitalization fund.

The question of national liability has been at the core of the political controversy. Whereas the original Spanish proposal for direct recapitalization of Spanish banks through the ESM would have provided for a Europeanization of legacy risks, channeling these funds through the Spanish government's recapitalization fund implied that the Spanish government itself would be liable for the debt service.

The BRRD and the SRM leave the principle of national fiscal responsibility for banks untouched. For the BRRD, which applies to the entire EU, this is a matter of course - as a directive, the BRRD merely provides the legal background to the Internal Market in banking and does not in itself promote the banking union. In the SRM, the issue is dealt with by denying that it is an issue at all. Claiming that recovery and resolution will be paid for by the industry without any imposition on taxpayers is a way to avoid taking a clear stand on fiscal responsibility. In a crisis, if the institutions that are at risk are sufficiently important, if national governments are unable to provide the requisite backstops, and ESM loans are insufficient, 
one may find out that the problem must be dealt with anyway. As in other contexts, the crisis may be used as an occasion for further integration, albeit by hurried stopgap measures.

In the political debate about the issue, legacy assets and legacy risks have played an important role. Even people who would in principle acknowledge that a mutualization of fiscal responsibilities for banks might serve a useful insurance function have argued that you shouldn't provide insurance for a house that is already on fire, i.e., any mutualization of fiscal responsibilities for risks in the financial system should not cover losses on existing assets. Given the externalities from keeping those losses hidden and having the weakness of financial institutions endanger financial stability and growth all over Europe, I do not find this argument altogether convincing. However, it has played an important role in the debate.

One might also argue the issue with a view to moral hazard. National policies affect the safety and soundness of banks in a given country, so fiscal responsibility for any bailouts would ensure that these risks are properly taken into account. But there is another side to the coin: Supranational institutions for supervision and resolution take decisions that affect risks to taxpayers. National fiscal responsibility may therefore generate moral hazard on the side of those institutions. Indeed, until now, this argument has played a major role in justifying national competence for supervision and even the subordination of supervision to the national finance minister. ${ }^{37}$ As constituted at present, therefore, the new regime is bound to raise questions about the legitimacy of decisions taken at the supranational level that impose fiscal burdens on national treasuries.

In the short run, there is a danger that the maintenance of national fiscal responsibility will deepen the split between "periphery" and "core" countries. There is also a danger that the cleanup of the financial system will be further delayed. Countries with sufficient fiscal capacity will be able to use the recapitalization option under BRRD to preempt any recovery and resolution procedure. At the level of the individual institution, this may be satisfactory, if costly for national taxpayers, but the needed adjustment of market structure will not take place. Countries that do not have the requisite fiscal capacity will try to continue sweeping problems under the rug; if this is not possible, they may again be forced to have recourse to ESM support. However, there will be enormous pressure on supervisors to exercise forbearance and act as if the problems with some of the banks' assets were merely temporary and hopes for an eventual recovery would justify asset valuations at which the banks can be deemed to be well capitalized.

From this perspective, it will be interesting to watch the Asset Quality Review that is to take place later this year. On the one hand, the ECB has a strong interest in ensuring that the Asset Quality Review is serious and that problems are laid open and remedied. Otherwise there is a risk of problems emerging soon after the SSM begins to work, which would be disastrous for the ECB's credibility. On the other hand, national authorities, and to some extent the ECB 
itself, have a strong interest in ensuring that not too many problems are laid open. Otherwise national authorities will be blamed for past laxness; moreover, the needed remedies and adjustments may not be feasible for some of the participants. At this point, the outcome of this conflict is up in the air.

In the medium run, I believe that banking union will require a Europeanization of fiscal responsibility. First, this would contribute to defusing the issue of loss sharing in dealing with banks that have significant cross-border operations, making single-entry resolution more palatable. Given that the US and the UK are not included, this would only be a small step, but one that is nevertheless worthwhile. Second, a Europeanization of fiscal responsibility is necessary for the protection of monetary policy. To the extent that national fiscal responsibility prevents a cleanup of the financial system, the ECB remains hostage to the weakness of the financial sector. In particular, there is little hope for overcoming the fragmentation of financial and monetary systems that we currently have. This fragmentation makes the ECB's task of ensuring monetary stability in the euro area all but impossible to fulfil. ${ }^{38}$

The question is whether a Europeanization of fiscal responsibility can be achieved without the creation of a European fiscal sovereign. The fiscal backstop that is needed for the SRM to be viable requires some tax base. So far, such a tax base does not exist. Will banking union become a reason for moving forward in this direction?

\section{Concluding Remarks}

As indicated by the preceding discussion, I am skeptical whether banking union as it has been designed so far will really allow us to deal with the problems that currently plague our financial sector. Whereas the Europeanization of supervision and the independence of supervision from political authorities may eliminate some of the distortions in supervision that we have seen in the past, the resolution regime remains nonviable in my view. "Too Big To Fail” is still with us. Moreover, the maintenance of national fiscal responsibility for banks preserves incentives to sweep problems under the rug, and preserves some of the factors that have been responsible for the fragmentation of financial and monetary systems that is plaguing the monetary union.

Politically, the development of banking union seems to involve a bet between the European institutions, in particular, the ECB, and the member states. From the perspective of the ECB, banking union holds the promise that, if it works, the ECB may get out of the straightjacket where it has to provide funding to banks, even if they are suspected to be insolvent, which then provide funding to their governments. From the perspective of those governments, bank-

38 In this context, it is worth noting that the German Constitutional Court's indictment of Outright Monetary Transactions placed particular weight on the selectiveness of the program, a selectiveness that seemed mandated by the fragmentation of the monetary systems but whose distributive implications the judges considered unpalatable. 
ing union holds the promise that the ECB is drawn even more deeply into being responsible for financial stability and therefore the indirect access to the printing press becomes even easier. Which side will win is unclear but it is by no means a foregone conclusion that it will be the ECB.

To be sure, European arrangements have always evolved dynamically, dealing with problems as they came along. One day's problems have often become the next day's reforms. In that sense, my skeptical remarks can be read as an agenda for further reform. I hope that this reform will come before the problems become unmanageable.

At a deeper level though, I am wondering. Banks are political and have always been. The example of Jakob Fugger financing Charles V's election to be Holy Roman Emperor is paradigmatic. So is the example of the Medici taking over the government of Florence in order to protect their bank from bankruptcy. The symbiosis of banks and treasuries has for centuries been a key element of sovereignty. Are member states really prepared to transfer this part of their sovereignty to the European institutions? I consider this transfer to be necessary if monetary union is to survive, but I wonder whether the political will is there.

However, if the European Monetary Union were to fall apart, the details could be ugly. In those countries where people expect claims on euros to be devalued, we must expect to see bank runs, breakdowns of banks and of payment systems, and severe economic and social crises. Economic and social damage could be enormous. So could be the effects on people's feelings about European integration and all that it stands for. 


\section{References}

Acharya, V.V., and Steffen, S. (2013), “The greatest carry trade ever? Understanding European bank risk”, Working paper, New York University and European School of Management and Technology.

Admati, A.R., and M.F. Hellwig (2013), The Bankers’ New Clothes, Princeton University Press, Princeton, N.J.

ASC (2012), “Forbearance, resolution and deposit insurance”, Report 01 of the Advisory Scientific Committee of the European Systemic Risk Board, Frankfurt, July 2012.

ASC (2014), “Is Europe Overbanked?”, Report 04 of the Advisory Scientific Committee of the European Systemic Risk Board, Frankfurt, June 2014.

Bernanke, B.S. (1983), "Nonmonetary effects of the financial crisis in propagation of the Great Depression”, American Economic Review 73 (3), 257 - 276.

Brealey, R.A., I. A. Cooper, and E. Kaplanis. (2011), “International Propagation of the Credit Crisis.” Mimeo. London Business School, London.

Caprio, G., and D. Klingebiel. (1996), “Bank Insolvencies, Cross-Country Experiences.” Policy Research Working Paper 1620. World Bank, Washington, DC.

Caprio, G., and D. Klingebiel (1997), “Bank Insolvency: Bad Luck, Bad Policy, or Bad Banking?” Paper written for the Annual World Bank Conference on Development Economics, April 25-26, 1996.

Curry, T., and L. Shibut. (2000), “The Costs of the Savings and Loan Crisis: Truth and Consequences.” FDIC Banking Review 13, 26-35.

Demirgüc-Kunt, A., E.Detragiache, and O. Merrouche. (2010), "Bank Capital: Lessons from the Financial Crisis.” Policy Research Working Paper 5473. World Bank, Washington, DC.

Dermine, J. (1990), European Banking in the 1990s, Blackwell Publishers, Oxford.

Eichengreen, B., and R. Hausmann (1999), „Exchange Rates and Financial Fragility”, in: New Challenges for Monetary Policy. Proceedings of a symposium sponsored by the Federal Reserve Bank of Kansas City.

European Commission (2013), State Aid No SA.29338 (2013/C-30) (ex 2013N-504) — Increase of the second-loss guarantee for HSH Nordbank AG, Invitation to submit comments pursuant to Article 108(2) TFEU , Official Journal 2013/C315/81 -/91, 
European Council (2012), Euro area summit statement, 29 June 2012, http://www.europeancouncil.europa.eu/home-page/highlights/euro-area-summit-statement.

FCIC (Financial Crisis Inquiry Commission) (2011), The Financial Crisis Inquiry Report. Washington, DC: U.S. Government Printing Office.

Friedman, M., and Schwartz, A.J. (1963), A monetary history of the United States 1867 1960, Princeton University Press, Princeton, N.J.

Goodhart, C.A.G. (1988), The Evolution of Central Banking, MIT Press, Cambridge, MA.

Hellwig, M.F. (1994), "Liquidity Provision, Banking and the Allocation of Interest Rate Risk”, European Economic Review 38: 1363-1389.

Hellwig, M.F. (2007), “Switzerland and Euroland: European Monetary Union, monetary stability and financial stability”, in: The Swiss National Bank 1907 - 2007, Verlag Neue Zürcher Zeitung, Zürich, 741 - 780.

Hellwig, M.F. (2009), "Systemic Risk in the Financial Sector: An Analysis of the SubprimeMortgage Financial Crisis.” The Economist 157, 129-207.

Hellwig, M.F. (2011) “Quo Vadis Euroland? European Monetary Union Between Crisis and Reform”, in: F. Allen, E. Carletti, G. Corsetti (eds.), Life in the Eurozone: With or Without Sovereign Default?, FIC Press, Wharton Financial Institutions Center, Philadelphia 2011, 59 - 76.

Hellwig, M.F. (2012), “The Problem of Bank Resolution Remains Unsolved: A Critique of the German Bank Restructuring Law.” In Too big to fail-Brauchen wir ein Sonderinsolvenzrecht für Banken?, ed. Patrick S. Kenadjian. Boston: De Gruyter. 35-62.

Hellwig, M.F. (2013), „Stellungnahme zur Anhörung des Haushaltsausschusses der Bürgerschaft der Freien und Hansestadt Hamburg über die Wiedererhöhung der Ländergarantie für HSH Nordbank am 30. April 2013“ (Statement before the Budget Committee of the Parliament of the City of Hamburg in a Hearing Concerning the Increase of State Guarantees for HSH Nordbank), Max Planck Institute for Research on Collective Goods, Bonn, http://www.coll.mpg.de/sites/www.coll.mpg.de/files/text/ Anhoerung_HSH_Nordbank.pdf

Hellwig, M.F. (2014), “Financial Stability, Monetary Policy, Banking Supervision and Central Banking”, Paper presented at the First ECB Forum, Sintra, May 25-26, 2014, mimeo, Max Planck Institute for Research on Collective Goods, Bonn, forthcoming in: European Central Bank (ed.), Monetary Policy in a Changing Financial Landscape, Proceedings of the First ECB Forum on Central Banking. 
Herring, R. and J. Carmassi. 2010. "The Corporate Structure of International Financial Conglomerates: Complexity and Its Implications for Safety and Soundness,” in: A. Berger, P. Molyneux and J. Wilson (eds.) The Oxford Handbook of Banking, Oxford University Press.

Hoshi, T., and Kashyap, A.K. (2004), “Japan’s financial crisis and economic stagnation”, Journal of Economic Perspectives 18 (Winter), 3 -26.

Hoshi, T., and Kashyap, A.K. (2010), “Why did Japan stop growing?”, NBER working paper, National Bureau of Economic Research, Cambridge, MA.

Miller, H.A., and M. Horowitz (2012), “A Better Solution is Needed for Failed Giants”, New York Times, October 9, 2012.

Pisani-Ferry, J., A. Sapir, N. Véron, and G.B. Wolff (2012), What Kind of European Banking Union?, Bruegel Policy Contribution 2012/12, Bruegel, Brussels.

Sapir, A., Hellwig, M.F., and Pagano, M. (2012), A contribution from the Chair and ViceChairs of the Advisory Scientific Committee to the discussion on the European Commission's banking union proposals, Report No. 2 of the Advisory Scientific Committee of the European Systemic Risk Board.

Wissenschaftlicher Beirat (2008), "Zur Finanzkrise", Brief des Wissenschaftlichen Beirats beim Bundesministerium für Wirtschaft und Technologie an den Bundesminister für Wirtschaft und Technologie Michael Glos vom 10. Oktober 2008 (“On the Financial Crisis“, Letter of October 10, 2008 from the Academic Advisory Committee of the Federal Ministry of Economic Affairs and Technology to the Federal Minister for Economic Affairs and Technology Michael Glos),

http://www.bmwi.de/BMWi/Redaktion/PDF/Publikationen/brief-wissenschaftlicher-beiratfinanzkrise,property=pdf,bereich=bmwi2012,sprache=de,rwb=true.pdf 